\title{
The unified framework for biological invasions: A forest fungal pathogen perspective
}

Michael J. Wingfield, Bernard Slippers, Brenda D. Wingfield, Irene Barnes*

\author{
Department of Genetics, Forestry and Agricultural Biotechnology Institute (FABI), University of \\ Pretoria, Pretoria 0002, South Africa
}

${ }^{*}$ I. Barnes (corresponding author)

e-mail: irene.barnes@fabi.up.ac.za

\section{Abstract}

Biological invasions in forests are growing in number and importance globally. The best studied examples are those caused by plants and animals including insects. In contrast, forest invasions caused by microbes including fungi have received much lower levels of attention, particularly in the invasion biology literature. This can at least to some extent be due to the large number of these organisms involved and the fact that the majority of these have yet to be discovered and described. This is equally true for tree-infecting fungi, many of which are devastating pathogens responsible for dramatic invasions in natural and planted forests. This situation is changing through the application of molecular genetic tools that make it possible to accurately identify fungal tree pathogens, to determine their origins, pathways of movement, their modes of reproduction and change; all of which can influence invasions. The role and relevance of symbioses between tree pathogens and insects in forest invasions is also gaining increased attention. So too is our understanding that trees live in close association with large numbers of microbes that make up their holobiome. This has substantial relevance to invasion biology (Zenni et al. 2017). This commentary highlights four emerging issues that need to be considered regarding the invasions by fungal pathogens of trees and it emphasizes opportunities to better understand their relevance and impacts on natural and planted forests. A call is also made for plant pathologists to work more closely with ecologists such that 
fungal pathogens become more commonly integrated into invasion biology programmes.

Keywords invasive fungi, invasive forest pathogen (IFP), symbioses, tree disease

\section{Introduction}

Invasion Biology was formulated little more than 50 years ago by Charles Elton via the publication of his monumental 1958 treatise "The Ecology of Invasions by Animals and Plants" (Elton 1958). Elton, who is broadly considered the 'father of the field of Invasion Biology' (Williamson 1996), barely considered microbial invasion in terms of human, animal and plant health and there were relatively few examples of insect pests presented in his work. Interestingly, Elton did include treatments of two North American tree-invasion problems; those of the devastating Chestnut Blight disease caused by the fungal pathogen Endothia parasitica (now Cryphonectria parasitica) and the gypsy moth (Lymantria dispar) invasion. From an ecological standpoint, invasions by plants and animals have received the bulk of attention. Although forests and woody ecosystems have become more prominent in the scientific literature in recent years, it is clearly a topic that deserves much greater attention, especially where forest pests and pathogens are concerned.

Four key steps have traditionally been used to describe the invasion process and these include (1) Transport, (2) Introduction, (3) Establishment, and (4) Spread of the invasive (Williamson 1996; Richardson et al. 2000; Duncan et al. 2003; Lockwood et al. 2008). Plant and animal ecologists have treated these steps differently mainly because they deal with very different taxa and often work in very different environments. Plant ecologists have traditionally adopted the terminologies of Richardson et al. (2000), considering the barriers that must be overcome before invasions are established. In contrast, animal ecologists have typically followed the definitions of Williamson (1996), that treat the stages of invasion moving from the native environment to becoming invasive aliens. These similar, but sometimes confusing approaches, have been effectively and elegantly consolidated in what was termed a "unified framework for biological invasions" by Blackburn et al. (2011). This 
"unified framework" sought to integrate the four major stages of invasion (a stagebased approach) with the barrier model, providing an effective terminology to describe the underpinning elements and processes involved in invasions.

While the Blackburn et al. (2011) "unified framework" can be broadly applied to biological invasions, it is predominantly focused on animal and plant examples. Microbiological invasions, caused by viruses, bacteria and fungi, for example, are mentioned, but insufficiently accommodated. In this regard, the vast diversity amongst the organisms termed as 'microbes' needs to be recognized. Here for perspective, it is sobering to recognize that the phylogenetic 'distance' between mammals and birds is equivalent to that amongst species of a single yeast genus, Saccharomyces (Dujon 2006). This does not yet include all fungi, and of course also not the even greater diversity amongst bacteria and viruses. It would be naïve to believe that the invasion biology of these organisms will not be significantly different to that of plants and animals. Lumping these organisms in a single treatment that is focused on plants and animals dilutes our opportunity to understand and to deal with them effectively.

Blackburn and Ewen (2017) provided a broad consideration of "parasites" in the invasion process without a specific focus on any particular group of invaders or their parasites. The added consideration in that paper is that, in order for invasion to be successful, pathogens need a host. This host would be either native or introduced along with the pathogen. Several implications of this situation are discussed in their work.

The present commentary adds to the views of Blackburn and Ewen (2017), specifically with relation to invasions by fungal pathogens of forests trees. In this regard, it seeks to extract a single group of microbes, in recognition of the huge diversity and very different biological strategies of microbial invaders. While this is a relatively narrow topic, it is of global and growing relevance. As mentioned previously, Elton (1958) included chestnut blight that has devastated natural Castanea dentate (March.) Borkh. forests in North America; the numbers of other such tree pathogens destroying both planted and natural forests continues to grow annually (Wingfield et al. 2015). The aim of this commentary is not to present lists of 
alien invasive fungal tree pathogens, a topic that has been well treated elsewhere (Desprez-Loustau et al. 2007; Loo 2009; Müller et al. 2016). Our intention is rather to highlight four emerging issues that are important to understand fungal invasions of forests, plantations and natural woody ecosystems, and that require more focused research in coming years. We hope to stimulate a better recognition of the importance of these issues and their integration with the invasion biology literature and ongoing research.

\section{UNDERLYING ECO-EVOLUTIONARY PROCESSES}

It would be fair to argue that we significantly lack a depth of knowledge regarding all invasions, irrespective of class of organisms involved. Zenni et al. (2017) have raised this issue seeking to highlight aspects concerned with evolutionary mechanisms to be considered as part of the 'unified framework' in addition to ecological aspects. These influencing factors include founder effects, epigenetics, population genetics, hybridization, genotype-by-environment interactions and the importance of symbionts (the so-called 'second genome'). These evolutionary mechanisms are poorly understood for most invasive aliens and this is certainly true in the case of fungal pathogens of forest trees.

The most comprehensively studied fungal tree pathogens are obviously those that we have known for the longest period of time and are all of northern hemisphere origin. These include the already mentioned chestnut blight pathogen, $C$. parasitica (Elton 1958; Hepting 1974; Anagnostakis 1987), the Dutch elm disease pathogens, Ophiostoma ulmi (Buisman) Nannf. and Ophiostoma novo-ulmi Brasier (Gibbs 1978; Brasier and Buck 2001), the white pine blister rust pathogen, Cronartium ribicola J.C. Fisch. (Butin 1995; Kinloch 2003), and Heterobasidion spp. (Woodward et al., 1998) For these pathogens, we have some knowledge of their origins, pathways of movement, spread and their population genetics (Et-Touil et al. 1999; Brasier 2001; Allen and Humble 2002; Hamelin et al. 2005; Milgroom et al. 2008). Some more recent invaders in these environments for which a growing body of knowledge is becoming available include Phytophthora ramorum and Hymenoscyphus fraxineus (Drenkhan et al. 2017; Grünwald et al. 2016; Prospero and Cleary 2017). Against the background of the large and growing numbers of fungal tree pathogens, this is a 
sparse base of knowledge. Yet we can, at least to some extent, apply this knowledge to some other tree pathogens and use it to motivate for studies on them.

Much of the work concerning fungal tree pathogens other than those mentioned above, and in other parts of the world, revolve around the identification, and in some cases the biology, of these organisms. In terms of tree health, proof of pathogenicity (Koch's Postulates) is a fundamental requirement. New tree pathogens are being recognized and described increasingly regularly. In some cases, knowledge is provided regarding host ranges and the environmental factors that allow infection to occur. This work is heavily skewed to pathogens of commercial importance such as those of trees grown for fruit production or forestry products. But even for these pathogens, there are relatively few examples where knowledge is available regarding their origins, population structures or pathways of spread. Notable examples include those for the pine needle pathogen Dothistroma (Figure 1c) (Dorogin) M. Morelet (Barnes et al. 2014; Drenkhan et al. 2016), the pine pitch canker pathogen Fusarium (Figure 1b) Nirenberg \& O'Donnell (Wingfield et al. 2008; Berbegal et al. 2013; Santana et al. 2016), the Eucalyptus stem canker pathogen Chrysoporthe cubensis (Bruner) Gryzenh. \& M.J. Wingf., as well as its close relatives (Gryzenhout et al. 2006; Nakabonge et al. 2006; Chen et al. 2010; Pegg et al. 2010; Van Der Merwe et al. 2013), and the Eucalyptus leaf pathogen Teratosphaeria nubilosa (Cooke) Crous \& U. Braun (Figure 1e) (Hunter et al. 2008; Hunter et al. 2009; Pérez et al. 2010). In these four cases, the pathogens are important to commercial forestry and this has, at least to some extent, provided the motivation and funding to study them.

There is a multiplicity of sexual reproductive systems in fungi (Taylor et al. 1999; Ni et al. 2011; Heitman et al. 2013; Wilson et al. 2015). These range from typical mating between strains having different mating types (heterothallism) to an ability to self (homothallism) where sexual outcrossing does not necessarily occur, but with a growing list of variants between these sexual systems (Lin and Heitman 2007; Wilson et al. 2015). There are also growing numbers of examples of fungi that have been shown to outcross despite the fact that they are also able to self (Perkins 1987; Milgroom et al. 1993; Lin and Heitman 2007), and these include examples of important tree pathogens and common invaders such as those in the Ceratocystidaceae (Harrington and Mcnew 1997; Witthuhn et al. 2000; De Beer et al. 

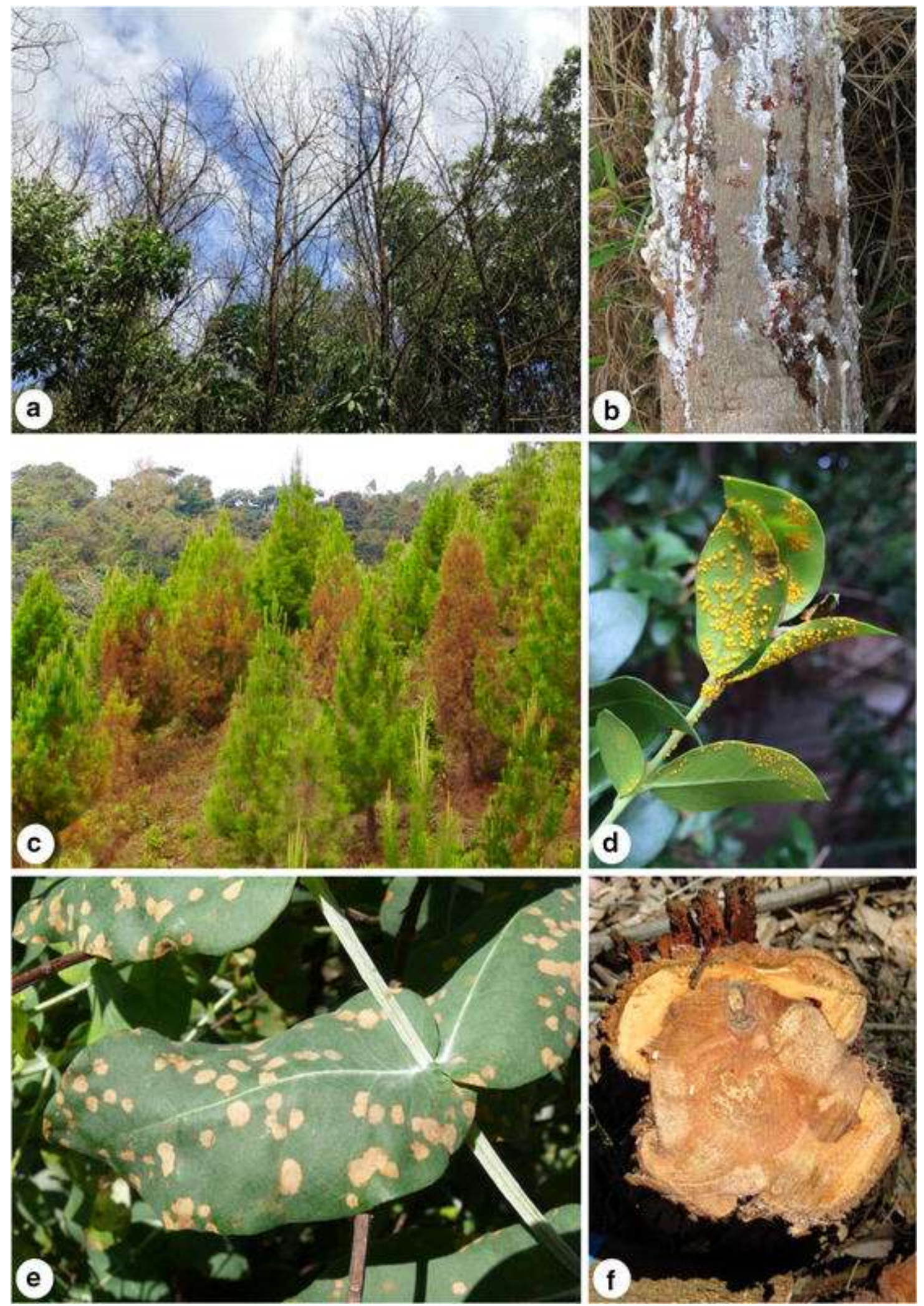

Fig. 1. Symptoms on trees affected by invasive fungal tree pathogens aAcacia mangium trees in Indonesia severely damaged by Ceratocystis manginecans, b Resious canker on Pinus patula in South Africa caused by Fusarium circinatum, $\mathbf{c}$ Damage to Pinus tecunumanii caused by the needle pathogen Dothistroma septosporum in Colombia, $\mathbf{d}$ Yellow spore masses of the myrtle rust pathogen Austropuccinia psidii on Backhousia citriodora in South Africa, e Leaf spots on Eucalyptus globulus in Uruguay caused by Teratosphaeria nubilosa,f Canker caused by Chrysoporthe cubensis on Eucalyptus grandis 
2014; Wilken et al. 2014; Lee et al. 2015). This complexity complicates the characterisation of fungal reproductive systems. Sexual outcrossing promotes diversity and could consequently influence the outcomes of invasions (Gladieux et al. 2015). Unfortunately these reproductive systems are poorly understood for many invading tree fungi. The increasing ease of sequencing fungal genomes and development of population genetics markers should help to address this shortcoming.

Reduced genetic diversity is expected in introduced populations in the early phases of the invasion as a consequence of founder effects or genetic bottlenecks (Sakai et al. 2001; Gladieux et al. 2015). Reduced genetic diversity can have a negative effect on populations due to the loss of alleles that might have adaptive value in a new environment (Sakai et al. 2001; Mcdonald and Linde 2002; Allendorf and Lundquist 2003). It can also have a positive effect through purging of deleterious alleles or maintenance of particularly successful genotypes. This is evident in some fungal pathogens of trees, especially where they are able to reproduce asexually or where clonal lineages of a single mating type dominates in an area. Cryphonectria parasitica, for example, has been shown to have colonized south-eastern Europe and it is spreading through many adjacent countries (Milgroom et al. 2008). These populations are all considered highly clonal with low levels of genetic diversity and vegetative compatibility groups, and the presence of a single dominant mating type (Milgroom et al. 2008; Dutech et al. 2012). Milgroom et al. (2008) proposed that these "clones have greater fitness than others" and that they are able to spread because they are well adapted to the new environmental conditions. Other examples of aggressive clonal lineages of fungal tree pathogens invading new areas include the "pandemic" strain of Austropuccinia (Puccinia) psidii on Myrtaceae (Ross-Davis et al. 2013; Mctaggart et al. 2016; Beenken 2017), Dothistroma septosporum on Pinus spp. in Australasia and South America (Barnes et al. 2014) and Ceratocystis platani on Platanus orientalis and P. $\times$ acerifolia in southern Europe (Ghelardini et al. 2017; Tsopelas et al. 2017).

The importance of hybridization in plant pathogen invasions is well recognized and there are growing numbers of examples of hybrid fungi resulting in serious tree diseases (Brasier et al. 1999; Brasier 2000; Newcombe et al. 2000; Brasier 2001; 
Gonthier et al. 2007; Érsek and Nagy 2008). Hybridisation and admixture are important sources of novel variation that could influence the evolution of fungal pathogens and their invasiveness (Brasier 2000; Allendorf and Lundquist 2003; Gladieux et al. 2015; Ghelardini et al. 2016). Interspecific hybridisation between two fungal species can produce hybrid species that have the ability to infect novel hosts with enhanced pathogenicity leading to greater levels of invasiveness than either of its parent species (Brasier 2001; Brasier and Buck 2001). For example, the hybridisation of introduced poplar rust pathogens Melampsora medusae and $M$. larici-populina in New Zealand resulted in a hybrid with a broader host range than that of the parent species (Spiers and Hopcroft 1994; Burdon et al. 2006). Similarly, the hybridisation of $M$. occidentalis and $M$. medusae that infect only Populus trichocarpa and $P$. deltoides, respectively, have hybridised to form the species Melampsora x columbiana. This phenotypically different species is capable of infecting both hosts mentioned above and hybrid clones of these hosts (Newcombe et al. 2000). In the oomycetes, an allopolyploid recombination between hybrids of Phytophthora alni uniformis and Phytophthora alni multiformis resulted in a new species, Phytophthora alni subsp. alni (Brasier et al. 2004). This persistent subspecies is part of a new taxon $(P$. alni), and is spreading throughout European riparian forests, killing Alnus trees (loos et al. 2006).

\section{INSECT SYMBIOSES}

In the case of fungal tree pathogens, symbioses are also fundamentally important for invasion success (Paine et al. 1997; Kirisits 2004; Six and Wingfield 2011). Symbioses with insects are prominent in this regard and include some of the most important alien invasives affecting forests and forestry (Wingfield et al. 2010; Hulcr and Dunn 2011; Ploetz et al. 2013). The classic example in this case is that of the Dutch Elm Disease (DED) fungi, Ophiostoma ulmi and O. novo-ulmi. The DED fungi are vectored by Scolytine (Coleoptera: Scolytinae) (Webber and Brasier 1984; Jacobi et al. 2013) that maturation feed on the twigs of healthy trees, allowing the pathogens to enter the vascular tissues and to result in rapid tree death (Gibbs 1978; Sinclair and Campana 1978; Gibbs et al. 1994). An interesting aspect of the invasion of these fungi in Europe and North America is that the pathogens have acquired native insect vectors in their invasive ranges (Wingfield et al. 2016; and see Ghelardini et al. 2017 
this issue). This has come about by these insects infesting pathogen infected wood that probably entered the invaded areas in untreated timber. In terms of invasion biology, the dangers of the movement of untreated timber and the emergence of diseases such as DED are increasingly being recognized (Roy et al. 2014; Wingfield et al. 2015).

The recent appearance of the dramatic wilt disease known as Laurel Wilt caused by the fungus Raffaelea lauricola T.C. Harr., Fraedrich \& Aghayeva provides another dramatic example of a symbiotic relationship between a wood-infesting beetle and a pathogenic fungus. The disease is devastating natural stands of Persea borbonia (L.) Spreng. (redbay) in the southeastern USA (Fraedrich et al. 2008; Hanula et al. 2008; Harrington et al. 2011). Neither the insects nor the fungal pathogen would most likely cause significant tree damage in the absence of the other, but rather it is their novel associations that are driving the epidemic.

The red turpentine beetle provides another example where the introduction of an invasive insect, along with its symbiont, is responsible for a dramatic forest disease outbreak. In its native range in North America, Dendroctonus valens Le Conte is not known as an aggressive pest and attacks only stressed or dying trees. In China, however, where $D$. valens was introduced into the country in the 1980 s, beetle attack of healthy native pines has resulted in millions of trees being killed (Sun et al. 2013). Based on population genetic analyses, eastern North America appears to be the likely source of the introduction (Taerum et al. 2016), most probably due to the intercontinental anthropogenic movement of woody material. The aggressive nature of the beetle in China is hypothesized to be due to the presence of its fungal symbiont Leptographium procerum (W.B. Kend.) M.J. Wingf. that most likely has been introduced from Europe (Taerum et al. 2013; Taerum et al. 2017). Although $L$. procerum is considered a commensalist fungus in North America and Europe (Jacobs and Wingfield 2001), it is apparently an aggressive pathogen of Asian pine and is only found in association with $D$. valens. The introduction of a non-aggressive pest and its association with a fungus in an area where together they form an aggressive beetle-fungal association highlights the complexity and risks associated with introductions linked to fungus beetle symbioses. 
The role of insects as 'drivers' of fungal tree pathogen invasions is well recognised for the symbiosis involving bark and wood-boring insects mentioned above (Wingfield et al. 2016). But there are growing numbers of tree-health problems where the relationship between the insect vector and fungal pathogen is apparently 'casual' with a range of insects. Ceratocystis pathogens of trees provide some of the best contemporary examples. For example, Ceratocystis albifundus M.J. Wingf., De Beer \& M.J. Morris, is native to southern Africa where it occurs on many native woody plants (Barnes et al. 2005; Roux and Wingfield 2013; Lee et al. 2016). The pathogen is vectored by sap-feeding nitidulid beetles (Coleoptera: Nitidulidae) that visit freshly made wounds on trees (Heath et al. 2009). These wounds provide the infection points for the pathogens to invade. In the case of $C$. albifundus, the fungus has become a serious pathogen of non-native Acacia mearnsii De Wild. (Roux et al. 2007; Roux and Wingfield 2009) and it now threatens to become an alien invasive in other parts of the world (Roux et al. 2001; Roux et al. 2005). A similar situation has recently emerged in South East Asia where the related C. manginecans M. van Wyk, Al-Adawi \& M.J. Wingf. (Van Wyk et al. 2007) has emerged as an important pathogen of non-native Acacia mangium (Figure 1a) (Tarigan et al. 2011; Brawner et al. 2015). While the origin of $C$. manginecans remains to be determined, preliminary evidence suggests that in some areas where disease occurs, the pathogen appears not to be native (Al Adawi et al. 2014; Fourie et al. 2016), but is vectored by bark beetle Hypocryphalus mangiferae Stebbing (Scolytinae) that has co-evolved with mango (Al Adawi et al. 2013).

Another significant issue affecting our understanding of invasions by fungi and their vectors in tree systems is the depth and coverage of sampling. The example of ambrosia beetles and their symbioses with fungi provides an apt example. With low or poor coverage, patterns of co-evolution have failed to emerge. However, these patterns are very obvious as sampling intensity is increased (Farrell et al. 2001; Kostovcik et al. 2015). Because there are increasing numbers of serious tree diseases caused by fungi associated with ambrosia beetles, for example the devastating Laurel wilt disease (Fraedrich et al. 2008; Hanula et al. 2008; Harrington et al. 2011), the role of novel fungal-insect associations in tree disease warrants much greater attention. 


\section{THE FUNGAL HOLOGENOME OF TREES}

There is a growing realization that organisms constitute complex systems that are sometimes referred to as the holobiont or hologenome (Bordenstein and Theis 2015). Consequently invasions are more complex than simply including the most prominent organism involved. For example, most tree invasions are closely linked to symbioses with microbes (ranging from parasitic to mutualistic, but with many not understood yet) although the microbes in these relationships have received much less attention than their plant hosts during invasions (Hayward et al. 2015; Blackburn and Ewen 2017; Zenni et al. 2017). For pines and many other trees, obligate mycorrhizal relationships are the most prominent of these symbioses (Chu-Chou 1979; Richardson et al. 1994; Díez 2005; Dickie et al. 2010; Hayward et al. 2015). In the case of the many legume tree invasive species, notably Acacia spp., their relationships with nitrogen fixing bacteria (rhizobia) is a requirement for establishment and consequently successful invasion (Rodríguez-Echeverría et al. 2009; Ndlovu et al. 2013). While these topics have been studied in some detail, their role in invasion biology requires considerably better understanding (Blackburn and Ewen 2017; Zenni et al. 2017).

It has been known for a number of decades that trees (and other plants) harbour large numbers and a great diversity of fungal endophytes (Ganley et al. 2004; Sieber 2007; Pirttilä and Frank 2011). Our understanding of these fungal tree microbiomes is cursory at best. This is both in terms of the composition, as well as the role (if any) of these organisms. It is evident from the few studies that have been undertaken that there are large numbers of fungal taxa resident in healthy tree tissues and these far exceed those that can be isolated using conventional microbiological methods. For example, Kemler et al. (2013), showed that single Eucalyptus trees potentially harbour thousands of fungal taxa and that many of these reside in fungal groups known to include tree pathogens (eg. the Mycosphaerellaceae and Teratosphaeriaceae). Molecular genetic tools to characterize the metagenomes of plants including trees are becoming increasingly available. Our knowledge of tree microbiomes and their role in both fungal and tree invasions is likely to grow rapidly. 
Some endophytes, such as members of the Botryosphaeriaceae, are well known latent pathogens, existing for long periods of time in asymptomatic tissue, but able to cause disease under conditions of stress (Slippers and Wingfield 2007; Marsberg et al. 2016). In this regard, movement of trees harbouring asymptomatic latent pathogens to areas where the trees are poorly suited to the prevailing environmental conditions can result in serious disease problems. Other than for the Botryosphaeriaceae, important examples are emerging for members of the Cryphonectriaceae that include some of the most aggressive pathogens of trees (Gryzenhout et al. 2009). These fungi can have a negative impact on the establishment of potentially invasive tree species (Wingfield 2003; Crous, et al. 2017). But there are also examples where the fungi are moved via traded plants or plant material to new environments where they become invasive aliens in their own right (Anderson et al. 2004; Santini et al. 2013; Marsberg et al. 2016). It is clear that future considerations on how we might tackle invasions by tree microbes that do not have any direct obvious effects on their hosts has been neglected and needs to be addressed.

\section{TAXONOMIC CONUNDRUMS}

Accurate and thus meaningful identification of fungi as a whole, including those that cause diseases of trees, has been a challenge for many years (Crous et al. 2016). Until only 30 years ago, the identification of fungi was based almost entirely on the morphological features of these organisms. Their relatively simple morphologies have consequently meant that the identification of many tree pathogenic fungi has been incorrect. The availability of DNA-based sequence technologies and thus phylogenetic inference has for the first time in centuries given rise to what will become a natural classification of these organisms. This technology has revolutionized fungal taxonomy not only providing universal bar-coding genes (Schoch et al. 2012; Stielow et al. 2015), but also the manner in which fungi are named (Hawksworth et al. 2011; Hawksworth 2015). Thus, the confusing 'dual nomenclature' system where the same fungi could have different names has now been replaced by the so-called 'One Fungus = One Name' (1F1N) classification (Taylor 2011; Wingfield et al. 2012). This alone will simplify fungal taxonomy and it will also substantially advance studies in fungal invasion biology. 
The incorrect identification of fungal tree pathogens prior to the availability of DNAbased techniques has caused considerable confusion in the plant pathology literature, including for some of the most important tree pathogens. For example, the canker pathogens in the Cryphonectriaceae are now known to include very distinct groups; those in the northern hemisphere that include the chestnut blight pathogen Cryphonectria parasitica (Murrill) M.E. Barr and those in the tropics and Southern Hemisphere in Crysoporthe including the Eucalyptus pathogen Chrysoporthe cubensis (Figure 1f) and its various sibling species (Heath et al. 2006; Gryzenhout et al. 2009). Likewise, tree pathogens previously treated in Ceratocystis including the DED pathogens are now known to reside in two different Orders of fungi. Moreover, they represent distinct genera and species complexes with significantly different ecologies (Hausner et al. 1993b, 1993a; Spatafora and Blackwell 1994; Seifert et al. 2013; Wingfield et al. 2017). Understanding these differences is already providing an improved knowledge relating to invasions caused by these fungi, and the picture that emerges is that fungal invasions are much more complex and frequent than previously realized.

One of the most vivid recent examples of problems relating to the identification of tree pathogens has been that concerning the myrtle rust pathogen $A$. psidii (Figure 1d). This pathogen is considered native to Central and South America and it is unusual amongst the rusts (Uredinales) in having a very broad range of hosts within Myrtaceae (Coutinho et al. 1998; Glen et al. 2007; Zhong et al. 2008; Carnegie et al. 2010; Giblin and Carnegie 2014). Austropuccinia psidii has been one of the most feared tree pathogens in Australia (Coutinho et al. 1998; Glen et al. 2007), a continent that has an extensive natural diversity in the Myrtaceae. When $A$. psidii reached Australia in 2010, it was argued that the invasion was of a different fungus known as Uredo rangelii J.A. Simpson, K. Thomas \& Grgur. (Carnegie et al. 2010). This fungus was believed to differ from $A$. psidii based on minor morphological difference in the urediniospores but mainly on the presence of a tonsure on this spore type (Simpson et al. 2006). This taxonomic confusion led to dissent regarding a tree disease that was spreading rapidly in Australia's natural environment and one that has now accumulated more than 232 different tree hosts (Carnegie et al. 2016). A more rapid identification of the pathogen applying the techniques that were 
commonly available at the time (Glen et al. 2007; Mctaggart et al. 2016), might not necessarily have reduced the impact of $A$. psidii in Australia, but it would at least have provided an impressive example of 'best practices' in dealing with invasive fungal pathogens.

\section{CONCLUSIONS}

In this paper we have highlighted some emerging issues pertaining to invasive fungi associated with trees. The topic, however, also has relevance to fungi as invasives in other ecosystems, such as agricultural systems, and also invasions by other microbes. We highlight four issues that are of particular relevance to understanding these invasions, but that are relatively poorly understood, and that are typically poorly considered in general invasion biology literature. These include biological issues relating to emergence of novel diversity through complex recombination and hybridization processes, as well as symbionts of fungal pathogens that are essential to their spread and host associations. We have also raised practical considerations such as the uncontrolled global movement of the endophytic fungal community with healthy plants, and the taxonomic issues that hamper the accurate identification of tree pathogens.

In eco-evolutionary terms, biological invasions have not been studied for particularly long time frames. Thus, seriously invasive alien organisms could cease to remain dominant over longer periods of time. As an example, trees that are invasive tend to be genetically uniform and in this respect they are not much different to those cultivated in uniform plantation environments. There is growing evidence to suggest that both native, as well as accidentally introduced pests and pathogens could eventually 'catch up' with these invasive plants and consequently reduce their impacts (Burgess and Wingfield 2017; Crous et al. 2017; Hurley et al. 2016). This might, for example, be considered the 'sting in the tail' of commercial tree-planting programmes that are clearly significantly threatened by pests and pathogens. It could also, at least partially, account for what is known as the 'boom and bust cycles', which are poorly understood and where invasive alien organisms suddenly cease to be invasive or disappear entirely. 
Invasion biology is beset by numerous conflicts of interest. These conflicts tend to obscure or even retard our understanding of them. For example, there are many tree species that are important commercially, but that are also considered noxious weeds. Invasion biologists seek to manage these problems using biological control strategies (Desprez-Loustau et al. 2007; Wood 2012; Hajek et al. 2016) but many of these can involve the introduction of tree pathogenic fungi. While these fungi might, on the one hand, reduce the invasiveness of the weed tree species, they also threaten commercial enterprises that rely upon these trees growing vigorously, as well as potentially the surrounding native systems. What is clearly required is common ground between parties seeking to grow trees and those that see the same tree species as a serious threat to the natural environment. This will require sober debate and a mutual understanding of often significantly opposing points of view.

Most studies dealing with invasion biology are dominated by zoologists and plant scientists with a strong interest in ecology. It is our view that most of these researchers have been trained in ecological theory and that this is a field that is not typically included in the curricula of plant pathologists. The education of microbiologists and pathologists tends to be more strongly focused on local and micro-processes, and individual organisms and their interactions. This is in contrast to a more complex and holistic community-environment interactions, and broad spatial scales. Although this might be an over-simplification, it is our impression that there remains a great need for deeper levels of communication and collaboration between invasion biologists and microbiologists that study, for example, fungal pathogens that are alien invasives.

Tree diseases caused by invasive alien fungal pathogens are increasing in number annually. These are seriously damaging to economies where the trees are grown for commercial purposes and they are destroying natural ecosystems, ultimately impacting negatively on general human well-being. There is clearly a great need for research to better understand these invasions and thus to provide opportunities to reduce their impact. In many cases, the technologies are already available to accurately identify the pathogens, to understand their pathways of introduction and to potentially manage their means of spread. What we lack is a considerably expanded 
effort to deal with these growing threats and to have the funding to apply these technologies.

\section{ACKNOWLEDGEMENTS}

We acknowledge the DST/NRF Centre of Excellence in Tree Health Biotechnology and the National Research Foundation (South Africa) for financial support. Photo credits go to Izette Greyling (Figure 1b) and Carlos Rodas (Figure 1c).

\section{REFERENCES}

Al Adawi, A. O.; R. M. Al Jabri; M. L. Deadman; I. Barnes; B. Wingfield; M. J. Wingfield, 2013: The mango sudden decline pathogen, Ceratocystis manginecans, is vectored by Hypocryphalus mangiferae (Coleoptera: Scolytinae) in Oman. European Journal of Plant Pathology, 135, 243-251.

Al Adawi, A. O.; I. Barnes; I. A. Khan; M. L. Deadman; B. D. Wingfield; M. J. Wingfield, 2014: Clonal structure of Ceratocystis manginecans populations from mango wilt disease in Oman and Pakistan. Australasian Plant Pathology, 43, 393-402.

Allen, E. A.; L. M. Humble, 2002: Non-indigenous species introductions: a threat to Canada's forests and forest economy. Canadian Journal of Plant Pathology, 24, 103-110.

Allendorf, F. W.; L. L. Lundquist, 2003: Introduction: population biology, evolution and control of invasive species. Conservation Biology, 17, 24-30.

Anagnostakis, S. L., 1987: The effect of multiple importations of pests and pathogens on a native tree. Biological Invasions, 3, 245-254.

Anderson, P. K.; A. A. Cunningham; N. G. Patel; F. J. Morales; P. R. Epstein; P. Daszak, 2004: Emerging infectious diseases of plants: pathogen pollution, climate change and agrotechnology drivers. Trends in Ecology and Evolution, $19,535-544$.

Barnes, I.; G. Nakabonge; J. Roux; B. D. Wingfield; M. J. Wingfield, 2005: Comparison of populations of the wilt pathogen Ceratocystis albifundus in South Africa and Uganda. Plant Pathology, 54, 189-195. 
Barnes, I.; M. J. Wingfield; I. Carbone; T. Kirisits; B. D. Wingfield, 2014: Population structure and diversity of an invasive pine needle pathogen reflects anthropogenic activity. Ecology and Evolution, 4, 3642-3661.

Beenken L, 2017: Austropuccinia: a new genus name for the myrtle rust Puccinia psidii placed within the redefined family Sphaerophragmiaceae (Pucciniales). Phytotaxa, 297, 53-61.

Berbegal, M.; A. Pérez-Sierra; J. Armengol; N. J. Grünwald, 2013: Evidence for multiple introductions and clonality in Spanish populations of Fusarium circinatum. Phytopathology, 103, 851-861.

Blackburn, T. M.; J. G. Ewen, 2017: Parasites as drivers and passengers of humanmediated biological invasions. EcoHealth, 14:61.

Blackburn, T. M.; P. Pyšek; S. Bacher; J. T. Carlton; R. P. Duncan; V. Jarošík; J. R. U. Wilson; D. M. Richardson, 2011: A proposed unified framework for biological invasions. Trends in Ecology and Evolution, 26, 333-339.

Bordenstein, S. R.; K. R. Theis, 2015: Host biology in light of the microbiome: ten principles of holobionts and hologenomes. PLoS Biology, 13, e1002226.

Brasier, C. M., 2000: Rise of the hybrid fungi. Nature, 405, 134-135.

Brasier, C. M., 2001: Rapid evolution of introduced plant pathogens via interspecific hybridisation. Bioscience, 51, 123-133.

Brasier, C. M.; K. W. Buck, 2001: Rapid evolutionary changes in a globally invading fungal pathogen (Dutch elm disease). Biological Invasions, 3, 223-233.

Brasier, C. M.; D. E. L. Cooke; J. M. Duncan, 1999: Origin of a new Phytophthora pathogen through interspecific hybridization. Proceedings of the National Academy of Science USA, 96, 5878-5883.

Brasier, C. M.; S. A. Kirk; J. Delcan; D. E. L. Cooke; T. Jung; W. A. Man In't Veld, 2004: Phytophthora alni sp. nov. and its variants: designation of emerging heteroploid hybrid pathogens spreading on Alnus trees. Mycological Research, 108, 1172-1184.

Brawner, J.; Y. Japarudin; M. Lapammu; R. Rauf; D. Boden; M. J. Wingfield, 2015: Evaluating the inheritance of Ceratocystis acaciivora symptom expression in a diverse Acacia mangium breeding population. Southern Forests: a Journal of Forest Science, 77, 83-90.

Burdon, J. J.; P. H. Thrall; L. Ericson, 2006: The current and future dynamics of disease in plant communities. Annual Review of Phytopathology, 44, 19-39. 
Burgess, T. I.; M. J. Wingfield, 2017: Pathogens on the move: A 100-year global experiment with planted eucalypts. Bioscience, 67, 14-25.

Butin, H., 1995: Tree diseases and disorders: causes, biology and control in forest and amenity trees. Oxford University Press, 252 pp.

Carnegie, A. J.; A. Kathuria; G. S. Pegg; P. Entwistle; M. Nagel; F. R. Giblin, 2016: Impact of the invasive rust Puccinia psidii (myrtle rust) on native Myrtaceae in natural ecosystems in Australia. Biological Invasions, 18, 127-144.

Carnegie, A. J.; J. R. Lidbetter; J. Walker; M. A. Horwood; L. Tesoriero; M. Glen; M. J. Priest, 2010: Uredo rangelii, a taxon in the guava rust complex, newly recorded on Myrtaceae in Australia. Australasian Plant Pathology, 39, 463466.

Chen, S.-F.; M. Gryzenhout; J. Roux; Y. Xie; M. J. Wingfield; X. D. Zhou, 2010: Identification and pathogenicity of Chrysoporthe cubensis on Eucalyptus and Syzygium spp. in South China. Plant Disease, 94, 1143-1150.

Chu-Chou, M., 1979: Mycorrhizal fungi of Pinus radiata in New Zealand. Soil biology and biochemistry, 11, 557-562.

Coutinho, T. A.; M. J. Wingfield; A. C. Alfenas; P. W. Crous, 1998: Eucalyptus Rust: A disease with the potential for serious international implications. Plant Disease, 82, 819-825.

Crous, C.; T. I. Burgesss, D. M. Richardson; M. J. Wingfield, 2016b: Ecological disequilibrium drives insect pest and pathogen accumulation on non-native trees. AoB Plant, plw081.

Crous CJ, Burgess TI, Le Roux JJ, Richardson DM, Slippers B, Wingfield MJ (2017) Ecological disequilibrium drives insect pest and pathogen accumulation in non-native trees. AoB Plant 9(1): plw081. doi: 10.1093/aobpla/plw081

Crous, P. W.; E. Z. Groenewald; B. Slippers; M. J. Wingfield, 2016a: Global food and fibre security threatened by current inefficiencies in fungal identification. Philosophical Transactions of the Royal Society B: Biological Sciences, 371, 20160024.

De Beer ZW, Duong TA, Barnes I, Wingfield BD, Wingfield MJ (2014) Redefining Ceratocystis and allied genera. Stud Mycol 79:187-219

Desprez-Loustau, M.-L.; C. Robin; M. Buée; R. Courtecuisse; J. Garbaye; F. Suffert; I. Sache; D. M. Rizzo, 2007: The fungal dimension of biological invasions. Trends in Ecology and Evolution, 22, 472-480. 
Dickie, I. A.; N. Bolstridge; J. A. Cooper; D. A. Peltzer, 2010: Co-invasion by Pinus and its mycorrhizal fungi. New Phytologist, 187, 475-484.

Díez, J., 2005: Invasion biology of Australian ectomycorrhizal fungi introduced with eucalypt plantations into the Iberian Peninsula. Biological Invasions, 7, 3-15.

Drenkhan, R.; H. Solheim; A. Bogacheva; T. Riit; K. Adamson; T. Drenkhan; T. Maaten; A. M. Hietala, 2017: Hymenoscyphus fraxineus is a leaf pathogen of local Fraxinus species in the Russian Far East. Plant Pathology, 66, 490-500.

Drenkhan, R.; V. Tomešová-Haataja; S. Fraser; R. E. Bradshaw; P. Vahalik; M. Mullett; J. Martín-García; L. Bulman; M. J. Wingfield; T. Kirisits; T. L. Cech; S. Schmitz; R. Baden; K. Tubby; A. Brown; M. Georgieva; A. Woods; R. Ahumada; L. Jankovsky; I. M. Thomsen; K. Adamson; B. Marcais; M. Vuorinen; P. Tsopelas; A. Koltay; A. Halasz; N. La Porta; N. Anselmi; R. Kiesnere; S. Markovskaja; A. Kačergius; I. Papazova-Anakieva; M. Risteski; K. Sotirovski; K. Lazarević; H. Solheim; P. Boroń; H. Braganca; D. Chira; D. L. Musolin; A. V. Selikhovkin; T. S. Bulgakov; N. Keča; D. Karadžić; V. Galovic; P. Pap; M. Markovic; L. Poljakovic Pajnik; V. Vasic; E. Ondrušková; B. Piskur; D. Sadiković; J. J. Diez-Casero; A. Solla; H. Millberg; J. Stenlid; A. Angst; V. Queloz; A. Lehtijärvi; H. T. Doğmuş-Lehtijärvi; F. Oskay; K. Davydenko; V. Meshkova; D. Craig; S. Woodward; I. Barnes, 2016: Global geographic distribution and host range of Dothistroma species: a comprehensive review. Forest Pathology, 46, 408-442.

Dujon, B., 2006: Yeasts illustrate the molecular mechanisms of eukaryotic genome. Trends in Genetics, 22, 375-387.

Duncan, R. P.; T. M. Blackburn; D. Sol, 2003: The Ecology of Bird Introductions. Annual Review of Ecology, Evolution, and Systematics, 34, 71-98.

Dutech, C.; B. Barres; J. Bridier; C. Robin; M. G. Milgroom; V. Ravignes, 2012: The Chestnut blight fungus world tour: successive introduction events from diverse origins in an invasive plant fungal pathogen. Molecular Ecology, 21, 39313946.

Elton, C. S., 1958: The ecology of invasions by plants and animals. The University of Chicago Press, Chicago and London, 181.

Érsek, T.; Z. Á. Nagy, 2008: Species hybrids in the genus Phytophthora with emphasis on the alder pathogen Phytophthora alni: a review. European Journal of Plant Pathology, 122, 31-39. 
Et-Touil, K.; L. Bernier; J. Beaulieu; J. A. Berube; A. Hopkin; R. C. Hamelin, 1999: Genetic structure of Cronartium ribicola populations in Eastern Canada. Phytopathology, 89, 915-919.

Farrell BD, Sequeira AS, O'Meara BC, Normark BB, Chung JH, Jordal BH (2001) The evolution of agriculture in beetles (Curculionidae: Scolytinae and Platypodinae). Evolution 55: 2011-2027.

Fourie, A.; M. J. Wingfield; B. D. Wingfield; P. Q. Thu; I. Barnes, 2016: A possible centre of diversity in South East Asia for the tree pathogen, Ceratocystis manginecans. Infection, Genetics and Evolution, 41, 73-83.

Fraedrich, S. W.; T. C. Harrington; R. J. Rabaglia; M. D. Ulyshen; A. E. Mayfield lii; J. L. Hanula; J. M. Eickwort; D. R. Miller, 2008: A fungal symbiont of the redbay ambrosia beetle causes a lethal wilt in redbay and other Lauraceae in the southeastern United States. Plant Disease, 92, 215-224.

Ganley, R. J.; S. J. Brunsfeld; G. Newcombe, 2004: A community of unknown, endophytic fungi in western white pine. Proceedings of the National Academy of Sciences of the United States of America, 101, 10107-10112.

Ghelardini, L.; N. Luchi; F Pecori; A. L. Pepori; R. Danit; G. Della Rocca; P. Capretti; P. Tsopelas, A. Santini, 2017: Ecology of invasive forest pathogens. Biological Invasions, this issue

Ghelardini, L.; A. L. Pepori; N. Luchi; P. Capretti; A. Santini, 2016. Drivers of emerging fungal diseases of forest trees. Forest Ecology and Management, 381, 235-246.

Gibbs, J.; C. M. Brasier; J. Webber, 1994: Dutch elm disease in Britain. Great Britain, Forestry Authority, Research Division.

Gibbs, J. N., 1978: Intercontinental epidemiology of Dutch elm disease. Annual Review of Phytopathology, 16, 287-307.

Giblin F, Carnegie AJ (2014) Puccinia psidii (Myrtle Rust) - Global host list. Version $\begin{array}{lllll}\text { current } & \text { at } & 24 & \text { Sept. }\end{array}$ https://www.anbg.gov.au/anpc/resources/Myrtle Rust.html Gladieux, P.; A. Feurtey; M. E. Hood; A. Snirc; J. Clavel; C. Dutech; M. Roy; T. Giraud, 2015: The population biology of fungal invasions. Molecular Ecology, 24, 1969-1986.

Glen, M.; A. C. Alfenas; E. a. V. Zauza; M. J. Wingfield; C. Mohammed, 2007: Puccinia psidii: a threat to the Australian environment and economy-a review. Australasian Plant Pathology, 36, 1-16. 
Gonthier, P.; G. Nicolotti; R. Linzer; F. Guglielmo; M. Garbelotto, 2007: Invasion of European pine stands by a North American forest pathogen and its hybridization with a native interfertile taxon. Molecular Ecology, 16, 13891400.

Grünwald, N. J.; M. Garbelotto; E. M. Goss; K. Heungens; S. Prospero, 2016: Emergence of the sudden oak death pathogen Phytophthora ramorum. Trends in Microbiology, 20, 131-138.

Gryzenhout, M.; B. D. Wingfield; M. J. Wingfield, 2009: Taxonomy, phylogeny, and ecology of bark-inhabiting and tree-pathogenic fungi in the Cryphonectriaceae. American Phytopathological Society (APS Press).

Gryzenhout, M.; C. A. Rodas; J. Mena Portales; P. Clegg; B. D. Wingfield; M. J. Wingfield, 2006: Novel hosts of the Eucalyptus canker pathogen Chrysoporthe cubensis and a new Chrysoporthe species from Colombia. Mycological Research, 110, 833-845.

Hajek, A.E.; B. P. Hurley; M. Kennis; J. R. Garnas; S. J. Bush; M. J. Wingfield, J. C. van Lenteren; M. J. W. Cock, 2016: Exotic biological control agents. A solution or a contribution to arthropod invasions. Biological Invasions, 18, 953-969.

Hamelin, R. C.; M. Allaire; M. J. Bergeron; M. C. Nicole; N. Lecours, 2005: Molecular epidemiology of white pine blister rust: recombination and spatial distribution. Phytopathology, 95, 793-799.

Hanula, J. L.; A. E. Mayfield; S. W. Fraedrich; R. J. Rabaglia, 2008: Biology and host associations of redbay ambrosia beetle (Coleoptera: Curculionidae: Scolytinae), exotic vector of laurel wilt killing redbay trees in the southeastern United States. Journal of Economic Entomology, 101, 1276-1286.

Harrington, T. C.; D. L. Mcnew, 1997: Self-fertility and uni-directional mating-type switching in Ceratocystis coerulescens, a filamentous ascomycete. Current genetics, 32, 52-59.

Harrington, T. C.; H. Y. Yun; S.-S. Lu; H. Goto; D. N. Aghayeva; S. W. Fraedrich, 2011: Isolations from the redbay ambrosia beetle, Xyleborus glabratus, confirm that the laurel wilt pathogen, Raffaelea lauricola, originated in Asia. Mycologia, 103, 1028-1036.

Hausner, G.; J. Reid; G. R. Klassen, 1993a: On the subdivision of Ceratocystis sl, based on partial ribosomal DNA sequences. Canadian Journal of Botany, 71, 52-63. 
_ 1993b: On the phylogeny of Ophiostoma, Ceratocystis ss, and Microascus, and relationships within Ophiostoma based on partial ribosomal DNA sequences. Canadian Journal of Botany, 71, 1249-1265.

Hawksworth, D. L., 2015: Proposals to clarify and enhance the naming of fungi under the International Code of Nomenclature for algae, fungi, and plants. IMA Fungus, 6, 199.

Hawksworth, D. L.; P. W. Crous; S. A. Redhead; D. R. Reynolds; R. A. Samson; K. A. Seifert; J. W. Taylor; M. J. Wingfield; O. Abaci; C. Aime; A. Asan; F.-Y. Bai; W. De Beer; D. Begerow; D. Berikten; T. Boekhout; P. K. Buchanan; T. I. Burgess; W. Buzina; L. Cai; P. F. Cannon; J. L. Crane; U. Damm; H.-M. Daniel; A. D. Van Diepeningen; I. Druzhinina; P. S. Dyer; U. Eberhardt; J. W. Fell; J. C. Frisvad; D. M. Geiser; J. Chirlei; C. Glienke; T. Gräfenhan; M. Groenewald; J. Z. Groenewald; J. De Gruyter; E. Guého-Kellermann; L.-D. Guo; D. S. Hibbett; S.-B. Hong; G. S. De Hoog; J. Houbraken; S. M. Huhndorf; K. D. Hyde; A. Ismail; P. R. Johnston; D. G. Kadaifciler; P. M. Kirk; U. Kõljalg; C. P. Kurtzman; P.-E. Lagneau; C. A. Lévesque; X. Liu; L. Lombard; W. Meyer; A. Miller; D. W. Minter; J. Najafzadeh; L. Norvell; S. M. Ozerskaya; R. Öziç; S. R. Pennycook; S. W. Peterson; O. V. Pettersson; W. Quaedvlieg; V. A. Robert; C. Ruibal; J. SchnüRer; H.-J. Schroers; R. G. Shivas; B. Slippers; H. Spierenburg; M. Takashima; E. Taşkın; M. Thines; U. Thrane; A. H. Uztan; M. Van Raak; J. Varga; A. Vasco; G. Verkley; S. I. R. Videira; R. P. De Vries; B. S. Weir; N. Yilmaz; A. Yurkov; N. Zhang, 2011: The Amsterdam declaration on fungal nomenclature. IMA Fungus, 2, 105-112.

Hayward, J.; T. R. Horton; A. Pauchard; M. A. Nuñez, 2015: A single ectomycorrhizal fungal species can enable a Pinus invasion. Ecology, 96, 1438-1444.

Heath, R. N.; M. Gryzenhout; J. Roux; M. J. Wingfield, 2006: Discovery of the Cryphonectria canker pathogen on native Syzygium species in South Africa. Plant Disease, 90, 433-438.

Heath, R. N.; M. J. Wingfield; M. Van Wyk; J. Roux, 2009: Insect associates of Ceratocystis albifundus and patterns of association in a native savanna ecosystem in South Africa. Environmental Entomology, 38, 356-364.

Heitman, J.; S. Sun; T. Y. James, 2013: Evolution of fungal sexual reproduction. Mycologia, 105, 1-27. 
Hepting, G. H., 1974: Death of the American chestnut. Journal of Forest History, 18, 60-67.

Hulcr, J.; R. R. Dunn, 2011: The sudden emergence of pathogenicity in insectfungus symbioses threatens naive forest ecosystems. Proceedings of the Royal Society of London B: Biological Sciences, 278, 2866-2873.

Hunter, G. C.; P. W. Crous; A. J. Carnegie; M. J. Wingfield, 2009: Teratosphaeria nubilosa, a serious leaf disease pathogen of Eucalyptus spp. in native and introduced areas. Molecular Plant Pathology, 10, 1-14.

Hunter, G. C.; N. A. Van Der Merwe; T. I. Burgess; A. J. Carnegie; B. D. Wingfield; P. W. Crous; M. J. Wingfield, 2008: Global movement and population biology of Mycosphaerella nubilosa infecting leaves of cold-tolerant Eucalyptus globulus and E. nitens Plant Pathology, 57, 235-242.

Hurley, B. P.; J. Garnas; M. J. Wingfield; M. Branco; D. M. Richardson; B. Slippers, 2016: Increasing numbers and intercontinental spread of invasive insects on eucalypts. Biological Invasions, 18, 921-933.

loos, R.; A. Andrieux; B. Marçais; P. Frey, 2006: Genetic characterization of the natural hybrid species Phytophthora alni as inferred from nuclear and mitochondrial DNA analyses. Fungal Genetics and Biology, 43, 511-529.

Jacobi, W. R.; R. D. Koski; J. F. Negron, 2013: Dutch elm disease pathogen transmission by the banded elm bark beetle Scolytus schevyrewi. Forest Pathology, 43, 232-237.

Jacobs, K.; M. J. Wingfield, 2001: Leptographium species: tree pathogens, insect associates and agents of blue-stain. American Phytopathological Society Press.

Kemler, M.; J. Garnas; M. J. Wingfield; M. Gryzenhout; K.-A. Pillay; B. Slippers, 2013: Ion Torrent PGM as tool for fungal community analysis: a case study of endophytes in Eucalyptus grandis reveals high taxonomic diversity. PLoS One, 8, e81718.

Kinloch, B. B., Jr, 2003: White pine blister rust in North America: past and prognosis. Phytopathology, 93, 1044-1047.

Kirisits, T., 2004: Fungal associates of European bark beetles with special emphasis on the ophiostomatoid fungi. In: Bark and wood boring insects in living trees in Europe, a synthesis: Springer, pp. 181-236. 
Kostovcik M, Bateman CC, Kolarik M, Stelinski LL, Jordal BH, Hulcr J (2015) The ambrosia symbiosis is specific in some species and promiscuous in others: evidence from community pyrosequencing. The ISME Journal, 9:126-138.

Lee, D.-H.; J. Roux; B. D. Wingfield; I. Barnes; L. Mostert; M. J. Wingfield, 2016: The genetic landscape of Ceratocystis albifundus populations in South Africa reveals a recent fungal introduction event. Fungal biology, 120, 690-700.

Lee, D. H.; J. Roux; B. D. Wingfield; M. J. Wingfield, 2015: Variation in growth rates and aggressiveness of naturally occurring self-fertile and self-sterile isolates of the wilt pathogen Ceratocystis albifundus. Plant Pathology, 64, 1103-1109.

Lin, X.; J. Heitman, 2007: Mechanisms of homothallism in fungi and transitions between heterothallism and homothallism. In: Sex in Fungi: molecular determination and evolutionary implication., Ed. by J. Heitman; J. W. Kronstad; J. W. Taylor; L. A. Casselton, Washington DC: American Society of Microbiology Press, pp. 35-57.

Lockwood, J. L.; M. F. Hoopes; M. P. Marchetti, 2008: Invasion Ecology. Blackwell Publishing Ltd.

Loo, J. A., 2009: Ecological impacts of non-indigenous invasive fungi as forest pathogens. Biological Invasions, 11, 81-96.

Marsberg, A.; M. Kemler; F. Jami; J. H. Nagel; A. Postma-Smidt; S. Naidoo; M. J. Wingfield; P. W. Crous; J. W. Spatafora; C. N. Hesse; B. Robbertse; B. Slippers, 2016: Botryosphaeria dothidea: A latent pathogen of global importance to woody plant health. Molecular Plant Pathology, Online, DOI:10.1111/mpp.12495.

Mcdonald, B. A.; C. Linde, 2002: Pathogen population genetics, evolutionary potential and durable resistance. Annual Review of Phytopathology, 40, 349379.

Mctaggart, A. R.; M. A. Van Der Nest; E. T. Steenkamp; J. Roux; B. Slippers; L. S. Shuey; M. J. Wingfield; A. Drenth, 2016: Fungal genomics challenges the dogma of name-based biosecurity. PLoS Pathog, 12, e1005475.

Milgroom, M. G.; S. E. Lipari; R. A. Ennos; Y.-C. Liu, 1993: Estimation of the outcrossing rate in the chestnut blight fungus, Cryphonectria parasitica. Heredity, 70, 385-392. 
Milgroom, M. G.; K. Sotirovski; D. Spica; J. E. Davis; M. T. Brewer; M. Milev; P. Cortesi, 2008: Clonal population structure of the chestnut blight fungus in expanding ranges in southeastern Europe. Molecular Ecology, 17, 4446-4458.

Müller, M. M.; L. Hamberg; J. Hantula, 2016: The susceptibility of European tree species to invasive Asian pathogens: a literature based analysis. Biological Invasions, 18, 1-11.

Nakabonge, G.; J. Roux; M. Gryzenhout; M. J. Wingfield, 2006: Chrysoporthe canker pathogens on Eucalyptus and Syzygium spp. in eastern and southern Africa. Plant Disease, 90, 734-740.

Ndlovu, J.; D. M. Richardson; J. R. U. Wilson; J. J. Le Roux, 2013: Co-invasion of South African ecosystems by an Australian legume and its rhizobial symbionts. Journal of Biogeography, 40, 1240-1251.

Newcombe, G.; B. Stirling; S. Mcdonald; H. D. Bradshaw, 2000: Melampsora $x$ columbiana, a natural hybrid of $M$. medusae and M. occidentalis. Mycological Research, 104, 261-274.

Ni, M.; M. Feretzaki; S. Sun; X. Wang; J. Heitman, 2011: Sex in fungi. Annual review of genetics, 45, 405-430.

Paine, T. D.; K. F. Raffa; T. C. Harrington, 1997: Interactions among scolytid bark beetles, their associated fungi, and live host conifers. Annual review of entomology, 42, 179-206.

Pegg, G. S.; M. Gryzenhout; C. O'dwyer; A. Drenth; M. J. Wingfield, 2010: The Eucalyptus canker pathogen Chrysoporthe cubensis discovered in eastern Australia. Australasian Plant Pathology, 39, 343-349.

Pérez, G.; B. Slippers; B. D. Wingfield; G. C. Hunter; M. J. Wingfield, 2010: Microand macrospatial scale analyses illustrates mixed mating strategies and extensive geneflow in populations of an invasive haploid pathogen. Molecular Ecology, 19, 1801-1813.

Perkins, D. D., 1987: Mating-type switching in filamentous ascomycetes. Genetics, 115, 215.

Pirttilä, A. M.; C. Frank, 2011: Endophytes of forest trees: biology and applications. Vol. 80, Springer Science \& Business Media.

Ploetz, R. C.; J. Hulcr; M. J. Wingfield; Z. W. De Beer, 2013: Destructive tree diseases associated with ambrosia and bark beetles: black swan events in tree pathology? Plant Disease, 97, 856-872. 
Prospero, S.; M. Cleary, 2017: Effects of host variability on the spread of invasive forest diseases. Forests, 8, 80, DOI:10.3390/f8030080

Richardson, D. M.; P. A. Williams; R. J. Hobbs, 1994: Pine invasions in the Southern Hemisphere: determinants of spread and invadability. Journal of biogeography, 21, 511-527.

Richardson, D. M.; P. Pyšek; M. Rejmánek; M. G. Barbour; F. D. Panetta; C. J. West, 2000: Naturalization and invasion of alien plants: concepts and definitions. Diversity and distributions, 6, 93-107.

Rodríguez-Echeverría, S.; J. A. Crisóstomo; C. Nabais; H. Freitas, 2009: Belowground mutualists and the invasive ability of Acacia longifolia in coastal dunes of Portugal. Biological Invasions, 11, 651-661.

Ross-Davis, A. L.; R. N. Graça; A. C. Alfenas; T. L. Peever; J. W. Hanna; J. Y. Uchida; R. D. Hauff; C. H. Kadooka; M. S. Kim; P. G. Cannon; S. Namba; N. Minato; S. Simento; C. A. Pérez; M. B. Rayamajhi; M. Morán; D. J. Lodge; M. Arguedas; R. Medel-Ortiz; M. A. López-Ramirez; P. Tennant; M. Glen; N. B. Klopfenstein, 2013: Tracking the distribution of Puccinia psidii genotypes that cause rust disease on diverse Myrtaceous trees and shrubs. In: Chadwick, K.; Palacios, P., comps. Proceedings of the 61st Annual Western International Forest Disease Work Conference; October 6-11, 2013; Waterton Lakes National Park; AB, Canada. Washington, DC: U.S. Department of Agriculture, Forest Service, Forest Health Protection. p. 131-137.

Roux, J.; M. J. Wingfield, 2009: Ceratocystis species: emerging pathogens of nonnative plantation Eucalyptus and Acacia species. Southern Forests: a Journal of Forest Science, 71, 115-120.

_- 2013: Ceratocystis species on the African continent, with particular reference to C. albifundus, an African species in the C. fimbriata sensu lato species complex. The Ophiostomatoid Fungi: Expanding Frontiers. Biodiversity Series, 12, 131-138.

Roux, J.; M. J. Wingfield; D. M. Byabashaija, 2001: First report of Ceratocystis wilt of Acacia mearnsii in Uganda. Plant Disease, 85, 1029-1029.

Roux, J.; R. N. Heath; L. Labuschagne; G. K. Nkuekam; M. J. Wingfield, 2007: Occurrence of the wattle wilt pathogen, Ceratocystis albifundus on native South African trees. Forest Pathology, 37, 292-302. 
Roux, J.; G. Meke; B. Kanyi; L. Mwangi; A. Mbaga; G. C. Hunter; G. Nakabonge; R. N. Heath; M. J. Wingfield, 2005: Diseases of plantation forestry trees in eastern and southern Africa. South African Journal of Science, 101, 409.

Roy, B. A.; H. M. Alexander; J. Davidson; F. T. Campbell; J. J. Burdon; R. Sniezko; C. Brasier, 2014: Increasing forest loss worldwide from invasive pests requires new trade regulations. Frontiers in Ecology and the Environment, 12, 547-465.

Sakai, A. K.; F. W. Allerndof; J. S. Holt, 2001: The population biology of invasive species. Annual Review of Ecology and Systematics, 32, 305-332.

Santana, Q. C.; M. P. A. Coetzee; B. D. Wingfield; M. J. Wingfield; E. T. Steenkamp, 2016: Nursery linked plantation-outbreaks and evidence for multiple introductions of the pitch canker pathogen Fusarium circinatum into South Africa. Plant Pathology, 65, 357-368.

Santini, A.; L. Ghelardini; C. D. Pace; M.-L. Desprez-Loustau; P. Capretti; A. Chandelier; T. Cech; D. Chira; S. Diamandis; T. Gaitniekis, 2013: Biogeographical patterns and determinants of invasion by forest pathogens in Europe. New Phytologist, 197, 238-250.

Schoch, C. L.; K. A. Seifert; S. Huhndorf; V. Robert; J. L. Spouge; C. A. Levesque; W. Chen; E. Bolchacova; K. Voigt; P. W. Crous, 2012: Nuclear ribosomal internal transcribed spacer (ITS) region as a universal DNA barcode marker for fungi. Proceedings of the National Academy of Sciences, 109, 6241-6246.

Seifert, K. A.; Z. W. De Beer; M. J. Wingfield, 2013: The ophiostomatoid fungi: expanding frontiers. CBS-KNAW Fungal Biodiversity Centre Utrecht.

Sieber, T. N., 2007: Endophytic fungi in forest trees: are they mutualists? Fungal Biology Reviews, 21, 75-89.

Simpson, J. A.; K. Thomas; C. A. Grgurinovic, 2006: Uredinales species pathogenic on species of Myrtaceae. Australasian Plant Pathology, 35, 549-562.

Sinclair, W. A.; R. J. Campana, 1978: Dutch Elm Disease. Perspectives after 60 years. Vol. 8, Ithaca: Cornell University Agricultural Experiment Station, 52 pp.

Six, D. L.; M. J. Wingfield, 2011: The role of phytopathogenicity in bark beetle-fungus symbioses: a challenge to the classic paradigm. Annual review of entomology, 56, 255-272.

Slippers, B.; M. J. Wingfield, 2007: Botryosphaeriaceae as endophytes and latent pathogens of woody plants: diversity, ecology and impact. Fungal Biology Reviews, 21, 90-106. 
Spatafora, J. W.; M. Blackwell, 1994: The polyphyletic origins of ophiostomatoid fungi. Mycological Research, 98, 1-9.

Spiers, A. G.; D. H. Hopcroft, 1994: Comparative studies of the poplar rusts Melampsora medusae, M. larisi-populina and their interspecific hybrid $M$. medusae-populina. Mycological Research, 98, 889-903.

Stielow, J. B.; C. A. Lévesque; K. A. Seifert; W. Meyer; L. Irinyi; D. Smits; R. Renfurm; G. J. M. Verkley; M. Groenewald; D. Chaduli, 2015: One fungus, which genes? Development and assessment of universal primers for potential secondary fungal DNA barcodes. Persoonia-Molecular Phylogeny and Evolution of Fungi, 35, 242-263.

Sun, J.; M. Lu; N. E. Gillette; M. J. Wingfield, 2013: Red turpentine beetle: innocuous native becomes invasive tree killer in China. Annual review of entomology, 58, 293-311.

Taerum, S. J.; T. A. Duong; Z. W. De Beer; N. Gillette; J.-H. Sun; D. R. Owen; M. J. Wingfield, 2013: Large shift in symbiont assemblage in the invasive red turpentine beetle. Plos One 8, e78126.

Taerum, S. J.; A. Konečný; Z. W. Beer; D. Cibrián-Tovar; M. J. Wingfield, 2016: Population genetics and symbiont assemblages support opposing invasion scenarios for the red turpentine beetle (Dendroctonus valens). Biological Journal of the Linnean Society, (Online), DOI:10.1111/bij.12781.

Taerum, S. J.; T. B. Hoareau; T. A. Duong, Z. W. De Beer; R. J. Jankowiak, M. J. Wingfield, 2017: Putative origins of the fungus Leptographium procerum. Fungal Biology, 121, 82-94.

Tarigan, M.; J. Roux; M. Van Wyk; B. Tjahjono; M. J. Wingfield, 2011: A new wilt and die-back disease of Acacia mangium associated with Ceratocystis manginecans and C. acaciivora sp. nov. in Indonesia. South African Journal of Botany, 77, 292-304.

Taylor, J. W., 2011: One fungus = One name: DNA and fungal nomenclature twenty years after PCR. IMA Fungus, 2, 113-120.

Taylor, J. W.; D. J. Jacobson; M. C. Fisher, 1999: The evolution of asexual fungi: reproduction, speciation and classification. Annual Review of Phytopathology, 37, 197-246.

Tsopelas, P.; A. Santini; M. J. Wingfield; Z. W. de Beer, 2017: Canker stain: A lethal disease destroying iconic plane trees. Plant Disease, 101:645-658. 
Van Der Merwe, N. A.; E. T. Steenkamp; C. Rodas; B. D. Wingfield; M. J. Wingfield, 2013: Host switching between native and non-native trees in a population of the canker pathogen Chrysoporthe cubensis from Colombia. Plant Pathology, 62, 642-648.

Van Wyk, M.; A. O. Al Adawi; I. A. Khan; M. L. Deadman; A. A. Al Jahwari; B. D. Wingfield; R. Ploetz; M. J. Wingfield, 2007: Ceratocystis manginecans sp. nov., causal agent of a destructive mango wilt disease in Oman and Pakistan. Fungal Diversity, 27, 213-230.

Webber, J. F.; C. M. Brasier, 1984: Transmission of Dutch elm disease: a study of the processes involved [Scolytidae]. Symposium series-British Mycological Society.

Wilken, P. M.; E. T. Steenkamp; M. J. Wingfield; Z. W. De Beer; B. D. Wingfield, 2014: DNA loss at the Ceratocystis fimbriata mating locus results in selfsterility. PloS one, 9, e92180.

Williamson, M., 1996: Biological invasions. Vol. 15, Springer Science \& Business Media.

Wilson, A. M.; P. M. Wilken; M. A. Van Der Nest; E. T. Steenkamp; M. J. Wingfield; B. D. Wingfield, 2015: Homothallism: an umbrella term for describing diverse sexual behaviours. IMA fungus, 6, 207-214.

Wingfield, M. J., 2003: Daniel McAlpine memorial lecture increasing threat of diseases to exotic plantation forests in the Southern Hemisphere: lessons from Cryphonectria canker. Australasian Plant Pathology, 32, 133-139.

Wingfield, M. J.; A. Hammerbacher; R. J. Ganley; E. T. Steenkamp; T. R. Gordon; B. D. Wingfield; T. A. Coutinho, 2008: Pitch canker caused by Fusarium circinatum - a growing threat to pine plantations and forests worldwide. Australasian Plant Pathology, 37, 319-334.

Wingfield, M. J.; B. Slippers; B. D. Wingfield, 2010: Novel associations between pathogens, insects and tree species threaten world forests. New Zealand Journal of Forestry Science, 40, S95-S103.

Wingfield, M. J.; E. G. Brockerhoff; B. D. Wingfield; B. Slippers, 2015: Planted forest health: the need for a global strategy. Science, 349, 9502-9507.

Wingfield, M. J; I. Barnes; Z. W. De Beer; J. Roux; B. D. Wingfield; S. J. Taerum, 2017: Novel associations between ophiostomatoid fungi, insects and tree 
hosts driving tree invasions: current status - future prospects. Biological Invasions, (this issue)

Wingfield, M. J.; J. R. Garnas; A. Hajek; B. P. Hurley, Z. W. de Beer; S. J. Taerum, 2016: Novel and co-evolved associations between insects and microorganisms as drivers of forest pestilence. Biological Invasions, 18, 10451056.

Wingfield, M. J.; Z. W. De Beer; B. Slippers; B. D. Wingfield; J. Z. Groenewald; L. Lombard; P. W. Crous, 2012: One fungus, one name promotes progressive plant pathology. Molecular Plant Pathology, 13, 604-613.

Witthuhn, R. C.; T. C. Harrington; B. D. Wingfield; J. P. Steimel; M. J. Wingfield, 2000: Deletion of the MAT-2 mating-type gene during uni-directional matingtype switching in Ceratocystis. Current Genetics, 38, 48-52.

Wood, A. R., 2012: Uromycladium tepperianum (a gall-forming rust fungus) causes a sustained epidemic on the weed Acacia saligna in South Africa. Australasian Plant Pathology, 41, 255-261.

Woodward, S.; J. Stenlid; R. Karjalainen; A. Hüttermann, 1998: Heterobasidion annosum: biology, ecology, impact and control. Wallingford: Cab International.

Zenni, R. D.; I. A. Dickie; M. J. Wingfield; H. Hirsch; C. J. Crous; L. A. Meyerson; T. I. Burgess; T. G. Zimmermann; M. M. Klock; E. Siemann; A. Erfmeier; R. Aragon; L. Moniti; J. J. Le Roux, 2017: Evolutionary dynamics of tree invasions: complementing the unified framework for biological invasions, $A \circ B$ Plants, 9, plw085.

Zhong, S.; B. Yang; A. C. Alfenas, 2008: Permanent genetic resources: development of microsatellite markers for the guava rust fungus, Puccinia psidii. Molecular ecology resources, 8, 348-350.

Kostovcik M, Bateman CC, Kolarik M, Stelinski LL, Jordal BH, Hulcr J (2015) The ambrosia symbiosis is specific in some species and promiscuous in others: evidence from community pyrosequencing. The ISME Journal, 9:126-138. 